\title{
The effect of dietary energy source on performance and nutrient digestibility in growing pigs
}

\author{
M.E.E. Ball',2,5, E. Magowan', V.E. Beattie ${ }^{3}$, K.J. McCracken', \\ W. Henry ${ }^{3}$, S. Smyth ${ }^{4}$, R. Bradford ${ }^{4}$, F.J. Gordon ${ }^{4}$ and C.S. Mayne ${ }^{1,2}$
}

\author{
'Agri-Food and Biosciences Institute, Large Park \\ Hillsborough, Co. Down BT26 6DR \\ ${ }^{2}$ The Queen's University of Belfast, School of Agriculture and Food Science \\ Newforge Lane, Belfast BT9 $5 P X$ \\ ${ }^{3}$ Devenish Nutrition Ltd. \\ 96 Duncrue Street, Belfast BT3 9AR \\ ${ }^{4} J o h n$ Thompson \& Sons Ltd. \\ 35-38 York Road, Belfast BT15 $3 G \mathrm{~W}$
}

(Received 11 November 2009; revised version 20 May 2010; accepted 16 August 2010)

\begin{abstract}
Seven experimental diets were formulated: basal diet (A) to which $19 \mathrm{~g} / \mathrm{kg}(\mathrm{B}), 38 \mathrm{~g} / \mathrm{kg}$ (C), $58 \mathrm{~g} / \mathrm{kg}$ (D) and $76 \mathrm{~g} / \mathrm{kg}$ (E) vegetable oil blend was added. Diets F and G were barley- and maizebased diets. Study 1 used 14 pigs to determine total tract digestibility and digestible energy (DE) content. The basal diet contained: g/ $\mathrm{kg}$ : barley 250 , wheat 160 , maize germ 65 , maize gluten 50 , maize gluten feed 50, wheat pollard 150, rapeseed 75, soyabean meal 163 and other ingredients 37. Study 2 used 1232 pigs on a performance trial. Digestibility coefficients were higher $(\mathrm{P}<0.001)$ for the cereal-based diets. Liveweight gain was highest $(\mathrm{P}<0.05)$ for pigs offered cereal-based diets but feed conversion efficiency (FCR) was similar compared with values obtained from pigs offered by-product-based diets plus oil. There was a significant $(\mathrm{P}<0.001)$ linear effect on FCR but not for DE:gain, with increasing oil addition. In conclusion, supplementation of by-product-based diets with oil increased DE to similar levels as cereal-based diets. However, cereal-based diets resulted in higher levels of DE intake and liveweight gain.
\end{abstract}

KEY WORDS: cereal, digestibility, oil, performance, digestible encrgy, pigs

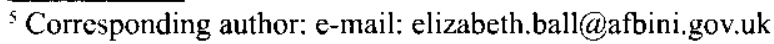




\section{INTRODUCTION}

The relationship between dietary energy content, feed intake and pig performance is complex and despite being an area of considerable research focus, the relationship is not yet completely understood. It is generally believed that pigs have the ability to 'eat to energy' and will adjust energy intake accordingly (Ellis and Augspurger, 2001). However, this is not always the case and the factors which affect feed intake (body weight, genotype, sex, etc.) influence the pig's ability to eat to energy. It is therefore important to be able to predict feed intake in order to supply energy requirements (Beaulieu et al., 2009). There are several equations that can predict feed intake (NRC, 1998; BSAS, 2003) and they can give a useful indication of intake potential. Cereal grains have traditionally been used by the pig industry as the main source of energy provided in the form of starch. However, in cereal deficient areas and depending on economic circumstances, cereal by-productbased diets plus oil have been utilized as an alternative source of energy. There has been a great deal of research conducted in the past in this area but the majority of previous studies investigated the effect of varying dietary energy content when intake was controlled (e.g., Campbell and Taverner, 1988) as opposed to ad libitum access. There is a lack of information in the literature on the utilization of energy from cereal or from oil when pigs are offered feed ad libitum and it is important that this is addressed as ad libitum access may result in higher than expected feed intakes despite the anticipated 'gut-fill' effect of higher fibre diets. The efficiency of utilization of energy from fat/oil is higher than the efficiency of utilization from protein, starch or fibre (Just, 1982) and Campbell and Taverner (1986) reported that growth rates and feed conversion efficiency improved as the energy density of the diet increased. However, Jongbloed et al. (1986) demonstrated that pigs performed differently when offered diets with similar energy values, but containing different ingredients. Pigs offered by-product-based diets plus $50 \mathrm{~g} / \mathrm{kg}$ oil performed worse than those offered cereal-based diets without oil. This may be a result of the digestible energy (DE) content of the added oil being overestimated, or due to an interaction between the oil and fibre dietary components. An interaction between fat and fibre has been reported by O'Doherty et al. (2002), who observed that the inclusion of 50 $\mathrm{g} / \mathrm{kg}$ fat $(60: 40 \%$ tallow and palm oil) improved $(\mathrm{P}<0.01)$ the $\mathrm{DE}$ content of diets containing $50 \mathrm{~g} / \mathrm{kg}$ crude fibre (CF), whereas, supplemental fat had no effect in diets with higher levels of CF (60 and $70 \mathrm{~g} / \mathrm{kg}$ ). However, Myer and Combs (1991) concluded that supplemental fat improved feed conversion efficiency with both low and high fibre diets and Overland et al. (1999) reported that pigs converted dietary energy from low-fat, high-fat, barley and oat based-diets with similar efficiency.

The objectives of the current study were to compare the performance of growing/finishing pigs given cereal-based diets to that of pigs given diets of 
similar DE contents containing substantial levels of by-products and added oil and to examine the response of pigs to increasing levels of oil supplementation of a low energy diet.

\section{MATERIAL AND METHODS}

\section{Experimental diets and animals}

Seven experimental diets were formulated: basal diet (A) to which $19 \mathrm{~g} / \mathrm{kg}$ (B), $38 \mathrm{~g} / \mathrm{kg}$ (C), $58 \mathrm{~g} / \mathrm{kg}$ (D) and $76 \mathrm{~g} / \mathrm{kg}$ (E) vegetable oil blend was added to give a range of digestible energy (DE) concentrations (Table 1). Diet F was mainly a barley-based diet with a calculated DE content intermediate to diets B

Table 1. Composition and formulated analysis of experimental diets

\begin{tabular}{|c|c|c|c|c|c|c|c|}
\hline \multirow{3}{*}{ ltem } & $\mathrm{A}$ & $\mathrm{B}$ & $\mathrm{C}$ & $\mathrm{D}$ & $\mathrm{E}$ & $\mathrm{F}$ & $\mathrm{G}$ \\
\hline & \multicolumn{5}{|c|}{ added oil, $\mathrm{g} / \mathrm{kg}$} & \multirow{2}{*}{ barley } & \multirow{2}{*}{ maize } \\
\hline & basal & 19 & 38 & 58 & 76 & & \\
\hline \multicolumn{8}{|l|}{ Composition, $\mathrm{g} / \mathrm{kg}$} \\
\hline barley & 250 & 245 & 241 & 236 & 231 & 456 & 249 \\
\hline wheat & 160 & 157 & 154 & 151 & 148 & 250 & 326 \\
\hline maize & - & - & - & - & - & - & 150 \\
\hline maize germ & 65 & 64 & 63 & 61 & 60 & - & - \\
\hline maize gluten & 50 & 49 & 48 & 47 & 46 & - & - \\
\hline maize gluten feed & 50 & 49 & 48 & 47 & 46 & - & - \\
\hline pollard & 150 & 147 & 144 & 141 & 139 & - & - \\
\hline rapeseed & 75 & 74 & 72 & 71 & 69 & - & - \\
\hline soyabean meal 50 & 163 & 160 & 157 & 154 & 151 & 247 & 227 \\
\hline herring meal & - & - & - & - & - & - & 10.4 \\
\hline vegetable oil blend & - & 19 & 38 & 35 & 76.8 & - & - \\
\hline molaferm & 10 & 10 & 10 & 10 & 10 & 10 & 10 \\
\hline limestone & 14.5 & 14.0 & 13.4 & 12.9 & 12.3 & 16.5 & 6.8 \\
\hline dicalcium phosphate & 2.9 & 2.8 & 2.8 & 2.7 & 2.7 & 11.1 & 11.3 \\
\hline salt & 2.6 & 2.6 & 2.5 & 2.5 & 2.5 & 3.2 & 3.2 \\
\hline lysine & 1.4 & 1.3 & 1.3 & 1.3 & 1.3 & 0.5 & 0.5 \\
\hline threonine & 0.25 & 0.25 & 0.24 & 0.24 & 0.23 & 0.25 & 0.25 \\
\hline trace minerals/vitamins & 5.0 & 5.0 & 5.0 & 5.0 & 5.0 & 5.0 & 5.0 \\
\hline \multicolumn{8}{|l|}{ Formulated analysis,g/kg } \\
\hline protein & 202 & 198 & 195 & 191 & 187 & 198 & 195 \\
\hline oil & 29 & 47 & 66 & 84 & 102 & 18 & 20 \\
\hline fibre & 49 & 49 & 48 & 47 & 46 & 32 & 27 \\
\hline lysine & 10.8 & 10.6 & 10.4 & 10.2 & 10.0 & 10.4 & 10.2 \\
\hline calcium & 9.1 & 8.9 & 8.6 & 8.4 & 8.1 & 11.0 & 7.5 \\
\hline phosphorus & 6.0 & 5.9 & 5.8 & 5.7 & 5.5 & 6.0 & 6.0 \\
\hline Digestible energy, $\mathrm{MJ} / \mathrm{kg}$ & 12.5 & 12.9 & 13.4 & 13.8 & 14.2 & 13.1 & 13.5 \\
\hline
\end{tabular}


and $\mathrm{C}$, while diet $\mathrm{G}$ was a cereal-based diet containing maize with a calculated $\mathrm{DE}$ content intermediate to $\mathrm{C}$ and $\mathrm{D}$. The diets were produced under commercial conditions at John Thompson and Sons Ltd., Belfast, and offered to pigs in two separate studics at two different pig units.

The pigs used in both studies were sired by the same genetic pool and both units operate as closed herds. Therefore, the genetic make-up of the pigs used in each study was similar.

\section{Pre-experimental period}

In both studies, pigs were weaned at 26 days of age and mixed to form groups of 22 (Study 1) and 20 (Study 2). From 10 days of age, piglets were offered a commercial creep feed which contained: $\mathrm{g} / \mathrm{kg}$ on fresh basis: crude protein $(\mathrm{CP})$ 220 , oil 110, ash 60, crude fibre (CF) 15 and lysine 17 . Between 4 and 7 weeks of age, the pigs were offered four commercial diets: $3 \mathrm{~kg} / \mathrm{pig}$ of diet 1 , followed by $3 \mathrm{~kg} / \mathrm{pig}$ of diet $2,6 \mathrm{~kg} / \mathrm{pig}$ of diet 3 and ad libitum access to diet 4 until allocation to treatment. Diet 1 contained: $\mathrm{g} / \mathrm{kg}$ on fresh basis: CP 235, oil 90, ash 60 , CF 20 and lysine 16.5 ; diet 2 contained: $\mathrm{g} / \mathrm{kg}$ on fresh basis: CP 210 , oil 80 , ash $60, \mathrm{CF}$ 30 and lysine 30 ; diet 3 contained: $\mathrm{g} / \mathrm{kg}$ on fresh basis: CP 220 , oil 66 , ash $65, \mathrm{CF}$ 25 and lysine 14, and diet 4 contained CP 207, oil 45, CF 28, ash 32 and lysine 12. Between 7 and 13 weeks of age, pigs were offered a grower diet which contained: $\mathrm{g} / \mathrm{kg}$ on fresh basis: CP 207, oil 45, ash 32, CF 28 and lysine 12 .

\section{Study 1}

At 13 weeks of age, 14 male (Large White $\mathrm{x}$ Landrace) pigs were randomized to the seven diets in a three period, partially balanced, crossover design resulting in six replicates/dietary treatment. Each period comprised a 7-day pre-feed and adaptation period and a 7-day total faecal collection period and pigs were housed in metabolic crates. Feed was offered at 900,1200 and $1500 \mathrm{~g} /$ day in periods I, II and III, respectively. Samples of the diets and faeces were collected and analysed to determine total tract apparent digestibility of DM, CP, lipid, neutral detergent fibre (NDF) and energy. Dietary DE content was also calculated. Proximate analyses were conducted according to the procedures outlined by the AOAC (1990). Lipid content was measured by the Oil Procedure B method as outlined in the Official Journal of the European Communities (1998). Gross energy was determined using an isoperibol bomb calorimeter (Parr, Model 1271). 
Study 2

This study was conducted on a large commercial farm where 1232 pigs were housed in pens of 22 (balanced for weight and gender) from 13 weeks of age $(41 \mathrm{~kg})$ and offered the experimental diets for 9 weeks until slaughter at approximately $91 \mathrm{~kg}$ liveweight. Pens had fully slatted concrete floors and automatically controlled natural ventilation. Pigs were offered feed ad libitum via two singlespace, wet and dry feeders per pen and fresh feed was supplied daily. Water was available from a nipple drinker in each feeder. There were eight replicates of the study, each involving approximately 154 pigs.

Production data were recorded (feed intake, liveweight gain (LWG) and feed conversion ratio (FCR). In addition, cold carcass weight, backfat depth at the $\mathrm{P}_{2}$ position and percentage lean content (as determined by the Ulster probe) were obtained at slaughter. Digestible energy content, calculated from Study 1, was used to determine DE intake (DEI), DE (MJ)/ $\mathrm{kg}$ gain and DE (MJ)/kg carcass gain.

\section{Statistical analysis}

The results from Study 1 were analysed by analysis of variance corresponding to the 14 pigs $\times 3$ periods, partially balanced, changeover design using Genstat 5 (1993). This corrected for the effects of pigs and periods and tested for the main effect of diet treatment.

The results from Study 2 were analysed by analysis of variance using Genstat 5 (1993). Data were blocked for replicate and mean initial weight of the pen of pigs was used as a covariate. Statistical analysis incorporated a test for a linear response to increasing dietary oil inclusion.

\section{RESULTS}

Study 1 - Total tract digestibility. Mean digestibility coefficients for DM, energy, CP and NDF were significantly higher $(9,9,6.5$ and $22 \%$, respectively) for the cereal diets than for diets A to $\mathrm{E}$ (Table 2). Lipid digestibility of diets $\mathrm{B}$ to $\mathrm{E}$ were higher $(16 \%)$ than for the cereal diets. There were no significant differences in digestibility coefficients between the cereal-based diets, but diet $\mathrm{G}$ (maize-based diet) contained a higher level of DE. There were no significant differences in the digestibility coefficients of diets $\mathrm{B}$ to $\mathrm{E}$, but digestibility of all parameters tended to be lower for diet A than for diets B to E. DE was calculated using the predicted chemical composition of the diets (Table 1). The determined 
Table 2. Total tract digestibility of experimental diets

\begin{tabular}{|c|c|c|c|c|c|c|c|c|c|}
\hline \multirow{3}{*}{ Item } & A & B & $\mathrm{C}$ & D & $\mathrm{E}$ & $\mathrm{F}$ & G & \multirow{3}{*}{ SEM } & \multirow{3}{*}{$\mathrm{P}$} \\
\hline & \multirow{2}{*}{ basal } & \multicolumn{4}{|c|}{ added oil, $\mathrm{g} / \mathrm{kg}$} & \multirow{2}{*}{ barley } & \multirow{2}{*}{ maize } & & \\
\hline & & 19 & 38 & 58 & 76 & & & & \\
\hline Dry matter & $0.760^{\mathrm{a}}$ & $0.780^{\mathrm{ab}}$ & $0.781^{b}$ & $0.779^{\mathrm{ab}}$ & $0.779^{\mathrm{ab}}$ & & $0.857^{\mathrm{c}}$ & & $<0.001$ \\
\hline & & & & & & & & & \\
\hline Lip & $0.686^{b}$ & $0.759^{\mathrm{c}}$ & $0.783^{c}$ & $0.799^{c}$ & $0.763^{\mathrm{c}}$ & $0.639^{\mathrm{a}}$ & $0.662^{\mathrm{ab}}$ & 0.0 & $<0.001$ \\
\hline NDF & $0.482^{\mathrm{a}}$ & $0.524^{\mathrm{ab}}$ & $0.535^{b}$ & $0.517^{\mathrm{ab}}$ & $0.540^{\mathrm{b}}$ & $0.620^{c}$ & $0.651^{\mathrm{c}}$ & 0.0157 & $<0.001$ \\
\hline Energy & $0.761^{\mathrm{a}}$ & $0.780^{\mathrm{ab}}$ & $0.783^{b}$ & $0.781^{\text {ab }}$ & $0.777^{\mathrm{ab}}$ & $0.839^{c}$ & $0.857^{\mathrm{c}}$ & 0.0073 & $<0.001$ \\
\hline $\mathrm{DE}, \mathrm{MJ} / \mathrm{kg} \mathrm{DM}$ & $14.0^{\mathrm{a}}$ & $15.1^{\mathrm{b}}$ & $15.1^{\mathrm{b}}$ & $15.4^{\mathrm{bc}}$ & $15.7^{\mathrm{c}}$ & $15.2^{\mathrm{b}}$ & $15.7^{\mathrm{c}}$ & 0.14 & $<0.001$ \\
\hline
\end{tabular}

${ }_{a, b}$ means with the same superscript are not significantly different

DE content of the by-product diets (A to C) were lower (2\%) than the calculated values and the determined values for the cereal diets $(F$ and $G)$ were higher $(2 \%)$ than the calculated values.

Study 2 - Performance. Energy source had a significant effect $(\mathrm{P}<0.001)$ on LWG, DFI, FCR, daily carcass gain, feed:carcass gain, actual DEI, $\mathrm{P}_{2}$ and percentage lean meat (Table 3). Feed intake on the basal diet (A) was 13\% higher

Table 3. The effect of energy source on performance of pigs within Study 2

\begin{tabular}{|c|c|c|c|c|c|c|c|c|c|}
\hline \multirow{3}{*}{ Item } & A & B & $\mathrm{C}$ & $\mathrm{D}$ & $\mathrm{E}$ & $\mathrm{F}$ & G & \multirow{3}{*}{ SEM } & \multirow{3}{*}{$P$} \\
\hline & \multirow{2}{*}{ basal } & \multicolumn{5}{|c|}{ added oil, $\mathrm{g} / \mathrm{kg}$} & & & \\
\hline & & 19 & 38 & 58 & 76 & barley & maize & & \\
\hline Initial weight, $\mathrm{kg}$ & 40.2 & 40.4 & 40.2 & 40.3 & 40.8 & 39.7 & 39.8 & 1.33 & 1.0 \\
\hline Final weight, kg & 90.7 & 91.7 & 91.8 & 91.8 & 89.7 & 93.4 & 90.9 & 1.02 & 0.3 \\
\hline Cold weight, $\mathrm{kg}$ & $66.9^{\mathrm{a}}$ & $67.4^{\mathrm{a}}$ & $67.0^{\mathrm{a}}$ & $67.6^{\mathrm{ab}}$ & $67.3^{\mathrm{a}}$ & $69.7^{\mathrm{c}}$ & $68.7^{\mathrm{bc}}$ & 0.43 & $<0.001$ \\
\hline Liveweight gain, g/day & $866^{\mathrm{ab}}$ & $884^{\mathrm{ab}}$ & $888^{\mathrm{ab}} \quad 8$ & $884^{\text {ab }}$ & $858^{\mathrm{a}}$ & $929^{c}$ & $900^{\mathrm{bc}}$ & 14.3 & 0.027 \\
\hline Feed intake, $\mathrm{kg}$ /day & $2.35^{\mathrm{d}}$ & $2.20^{\mathrm{b}}$ & $2.16^{\mathrm{ab}}$ & $2.17^{\text {ab }}$ & $2.08^{\mathrm{a}}$ & $2.30^{\mathrm{cd}}$ & d $2.21^{\mathrm{bc}}$ & 0.033 & $<0.001$ \\
\hline Feed conversion ratio & $2.72^{b}$ & $2.49^{\mathrm{a}}$ & $2.44^{\mathrm{a}}$ & $2.46^{\mathrm{a}}$ & $2.44^{\mathrm{a}}$ & $2.48^{\mathrm{a}}$ & $2.46^{\mathrm{a}}$ & 0.038 & $<0.001$ \\
\hline Daily carcass gain, $g /$ day & $630^{\mathrm{a}}$ & $638^{a}$ & $634^{a} \quad 6$ & $641^{a}$ & $645^{\mathrm{a}}$ & $689^{b}$ & $683^{b}$ & 8.4 & $<0.001$ \\
\hline Feed:carcass gain & $3.74^{\mathrm{d}}$ & $3.45^{\mathrm{c}}$ & $3.41^{\mathrm{c}}$ & $3.39^{\mathrm{bc}}$ & $3.23^{\mathrm{a}}$ & $3.34^{\mathrm{abc}}$ & $3.25^{\mathrm{ab}}$ & 0.051 & $<0.001$ \\
\hline $\begin{array}{l}\text { DE intake, } \mathrm{MJ} / \text { day } \\
\text { (calculated) }\end{array}$ & 29.4 & 28.5 & 28.9 & 30.0 & 29.7 & 30.1 & 29.9 & 0.44 & 0.12 \\
\hline $\begin{array}{l}\mathrm{DE} \text { intake, } \mathrm{MJ} / \text { day } \\
\text { (determined) }\end{array}$ & $28.9^{\mathrm{ab}}$ & $28.1^{\mathrm{a}}$ & $28.7^{\mathrm{ab}}$ & $29.5^{\mathrm{bc}}$ & $28.8^{\mathrm{ab}}$ & $30.6^{\mathrm{c}}$ & $30.5^{\mathrm{c}}$ & 0.44 & $<0.001$ \\
\hline $\begin{array}{l}\mathrm{DE}(\mathrm{MJ}) / \mathrm{kg} \text { gain } \\
\text { to } \mathrm{DE} \text { :gain }\end{array}$ & 33.5 & 31.8 & 32.4 & 33.4 & 33.6 & 33.0 & 34.0 & 0.50 & 0.054 \\
\hline $\begin{array}{l}\mathrm{DE}(\mathrm{MJ}) / \mathrm{kg} \text { carcass } \\
\text { to } \mathrm{DE} \text { : carcass gain }\end{array}$ & 46.0 & 44.1 & 45.3 & 46.1 & 44.6 & 44.4 & 44.8 & 0.68 & 0.26 \\
\hline $\mathrm{P}_{2}, \mathrm{~mm}$ & $10.1^{\mathrm{a}}$ & $10.1^{\mathrm{a}}$ & $10.3^{\mathrm{ab}}$ & $11.1^{\mathrm{c}}$ & $11.1^{\mathrm{c}}$ & $10.9^{\mathrm{bc}}$ & $11.0^{c}$ & 0.24 & 0.001 \\
\hline Killing out percentage & 73.9 & 73.5 & 73.1 & 73.7 & 75.2 & 74.7 & 75.7 & 0.74 & 0.14 \\
\hline Lean meat, $\%$ & $57.3^{\mathrm{bc}}$ & $57.4^{\mathrm{c}}$ & $57.1^{\mathrm{bc}}$ & $56.3^{\mathrm{a}}$ & $56.2^{\mathrm{a}}$ & $56.9^{\mathrm{abc}}$ & $56.6^{\mathrm{ab}}$ & 0.26 & 0.005 \\
\hline
\end{tabular}


than for diet $\mathrm{E}$ ( $76 \mathrm{~g} / \mathrm{kg}$ added oil), and feed intake on the cereal-based diets was higher $(5 \%)$ than for the by-product-based diets of equivalent DE content. LWG was highest for pigs offered the diets which included cereals as the source of energy ( $\mathrm{F}$ and $\mathrm{G})$. FCR was poorest for the basal diet $(\mathrm{A})(\mathrm{P}<0.001)$ while the other treatments were not significantly different from each other, the mean value being 2.46 . Feed: carcass gain improved by $14 \%(\mathrm{P}<0.001)$ with increasing oil concentration over diets $A$ to $E$ and the values for the cereal diets were similar to that for diet $\mathrm{E}$. Calculated DE intake (based on feed formulation matrix) was similar across all treatments but, based on the digestibility studies, DE intake was $6 \%$ higher $(\mathrm{P}<0.001)$ for the cereal diets.

There were no significant dietary effects on $\mathrm{DE}(\mathrm{MJ}) / \mathrm{kg}$ gain to $\mathrm{DE}$ : gain and $\mathrm{DE}(\mathrm{MJ}) / \mathrm{kg}$ carcass to DE: carcass gain, the mean values being 33.1 and $45.0 \mathrm{MJ}$, respectively. Backfat thickness at the $\mathrm{P}_{2}$ position averaged $10.2 \mathrm{~mm}$ for diets A to $\mathrm{C}$ while the high oil and cereal treatments averaged $11.0 \mathrm{~mm}(\mathrm{P}<0.001)$. Pigs offered diets $\mathrm{A}$ to $\mathrm{C}$ had a higher $(\mathrm{P}<0.01)$ lean meat percentage than those offered dicts D-G (57.3 vs $56.5 \%$ ).

Linear trends corresponding to increasing dietary oil inclusion were significant for feed intake, FCR, feed:carcass gain, $\mathrm{P}_{2}$ and lean meat percentage $(\mathrm{P}<0.001)$. Feed intake and lean meat percentage linearly decreased, while $\mathrm{P}_{2}$ increased (10.1 to $11.2 \mathrm{~mm}$ ). FCR and feed:carcass gain improved with increasing dietary oil inclusion.

\section{DISCUSSION}

The addition of oil to low energy by-product components resulted in diets of similar digestible energy (DE) to cereal-based diets and consequently improved feed conversion efficiency and feed to carcass gain compared with the basal diet. Overland et al. (1999) reported that supplemental oil improved growth, but in the current study oil addition had no effect on weight gain $(\mathrm{P}>0.05)$, although feed efficiency was improved ( 2.72 by-product vs 2.46 by-product plus oil-based diets) with oil added at any level. While actual feed intake was reduced as a result of added oil, DE intake was maintained, indicating that at increasing energy levels the pigs were able to regulate intake to satisfy energy requirements. This is in keeping with the findings of Ellis and Augspruger (2001) and Weatherup et al. (2002). However, for the cereal-based diets, DE intake was higher suggesting that pigs were able to eat the cereal-based diets to their ingestive capacity regardless of dietary energy content thus consuming more energy. The higher feed intake associated with cereal-based diets may be attributed to higher palatability of the diet due to the lower oil content. Supplemental oil has been shown previously 
to exert a negative effect on feed intake (e.g., Tribble et al., 1979). Gregory and Rayner (1987) concluded that supplemental fat inhibited feed intake in studies on the influence of gastrointestinal infusion of fat in pigs due to stimulation of cholecystokinin release. However, it is more probable that the higher feed intake was as a result of lower gut fill due to the lower fibre content in the cereal-based diets. Further research is required to investigate the reason for the effect on feed intake in the present study and to establish if the feed intake reduction in diets containing oil was due to reduced palatability or higher gut-fill. Feed intake and energy intake in the current study were similar to the values predicted using the equations given by Whittemore et al. (2003) indicating that the equations are an accurate method of predicting intake in pigs.

DM digestibility was higher for cereal-based diets and this is an important consideration, given the current legislative pressure on storing and spreading of pig slurry. A higher DM digestibility will result in slurry with a lower DM content, thus the overall volume of slurry will be reduced with cereal-based diets. Similarly, CP digestibility was lower for the by-product-based diets than for the cereal-based diets which is in keeping with previous studies (Bakker et al., 1995) and can be attributed to increased microbial fermentation as a result of higher levels of dietary fibre. CP digestibility was not improved by oil addition $(\mathrm{P}>0.05)$ which is in contrast to several other studies (e.g., Li and Sauer, 1994; Bakker et al., 1995). Li and Sauer (1994) determined ileal amino acid digestibility and found that the apparent digestibility of several amino acids increased linearly with increasing dietary fat levels, possibly due to delayed gastric emptying and a subsequent slower rate of passage in the small intestine.

Lipid digestibility was improved with oil addition $(\mathrm{P}<0.001)$. This effect can be attributed to the fact that supplemental dietary oil is more digestible than oil in other dietary components and also because there is less of an impact of endogenous oil excretion in the faeces (Just, 1982; O’Doherty et al., 2002). The lack of a linear trend on oil digestibility with increasing levels of supplemental oil would support the latter theory of lower impact on endogenous oil excretion in the faeces.

Improvements in feed conversion efficiency with oil addition, without effects on DE:gain suggests that utilization of energy from supplemental oil was similar to that from cereals (Overland et al., 1999). This finding is in contrast to Jongbloed et al. (1986) who concluded that pigs performed worse on diets containing oil as the energy source compared to those on diets of similar energy values but composed of different ingredients. In keeping with the results of Beaulieu et al. (2009), backfat at the $P_{2}$ position increased with increasing oil addition. However, the increase would not result in any grading penalties but is nonetheless an important factor to consider when using high levels of oil to increase dietary energy. 
The discrepancies between calculated and determined DE values were relatively small, but the combined effect of an overestimation of DE content in oil or by-products and underestimation of DE content in cereal may be important in commercial situations. The overestimation of DE content with oil has been reported previously. Jongbloed et al. (1986) concluded that energy from different sources were utilized differently. As actual DE was determined in this study it can be concluded that there was no difference of any practical significance in the utilization of energy from different dietary sources. Beaulieu et al. (2009) also highlighted the need to measure actual DE in studies investigating energy utilization in pigs due to deviations between formulated and actual DE as a result of variation in raw material composition.

\section{CONCLUSIONS}

In conclusion, by-product-based diets supplemented with oil (at levels as low as $1.9 \mathrm{~g} / \mathrm{kg}$ ) can increase digestibile energy content to levels equivalent to cerealbased diets. However, cereal-based diets resulted in greater feed intakes and liveweight gain than by-product-based diets supplemented with oil.

\section{REFERENCES}

AOAC, 1990. Association of Official Analytical Chemists, Official Methods of Analysis. 15 Fdition. Arlington, VA

Bakker G.C.M., Jongblocd R., Verstegen M.W.A., Jongbloed A.W., Borch M.W., 1995. Nutrient apparent digestibility and the performance of growing fattening pigs as affected by incremental additions of fat to starch or nonstarch polysaccharides. Anim. Sci. 60, 325-335

Beaulicu A.D., Williams N.H., Patience J.F., 2009. Response to dietary digestible energy concentration in growing pigs fed cereal grain-based diets. J. Anim. Sci. 87, 965-976

Campbell R.G., Taverner M.R., 1986. The effects of dietary fibre, source of fat and dietary energy content on the voluntary energy intake and performance of growing pigs. Anim. Prod. 43, 327

Campbell R.G., Taverner M.R., 1988. Genotype and sex effects on the relationship between energy intake and protein deposition in growing pigs. J. Anim. Sci. 66, 676-686

Ellis M., Augspurger N., 2001. Feed intake in growing-finishing pigs. In: A.J. Lewis, L.L. Southern (Editors). Swine Nutrition. CRC Press, Boca Raton, FL, pp. 447-467

Genstat 5 Committee, 1993. Genstat 5 Reference Manual. Clarendon Press, Oxford (England)

Gregory P.C., Rayner D.V., 1987. The influence of gastrointestinal infusion of fats on regulation of food intake in pigs. J. Physiol. 385, 471-481

Jongbloed A.W., van Diepen J.Th.M., Smits B., 1986. The effects of diets predominantly based on cereals or by-products on the performance of growing pigs. Report No. 176, IVVO-DLO, Lelyitad (The Netherlands)

Just A., 1982. The net energy value of balanced diets for growing pigs. Livest. Prod. Sci. 8, 541555 
Li S., Sauer W.C., 1994. The effect of dietary fat content on amino acid digestibility in young pigs. J. Anim. Sci. 72, 1737-1743

Myer R.O., Combs G.E., 1991. Fat supplementation of diets containing a high level of oats for growing-finishing swine. J. Anim. Sci. 69, 4665-4669

NCR, 1998. Nutrient Requirements of Swine. National Research Council. 10 $0^{\text {th }}$ revised Edition. National Academic Press. Washington, DC

O'Doherty J.V., McGlynn S.G., Murphy D., 2002. The influence of fibre level and fat supplementation in expander-processed diets on grower-finisher pig performance. J. Sci. Food Agr. 82, 10361043

Official Journal of the European Communities, 1998. L.257, 19/09/1998, p. 14

Overland M., Rorvik K.-A., Skrele A., 1999. High fat diets improve the performance of growingfinishing pigs. Acta Agr. Scand. 49, 83-88

Tribble L.F., Ingham S.H., Garkins C.T., Ramscy C.B., 1979. Evaluation of allied fat and lysine to sorghum-soyabean meal diets for swinc. J. Anim. Sci. 48, 541-546

Weatherup R.N., Beattie V.E., McCracken K.J., Henry R.W., Mcllroy S.G., 2002. The effects of energy and protein concentration in grower diets for pigs on performance from 8 to 12 weeks of age. Irish J. Agr. Food Res. 41, 95-104

Whittemore C.T., Hazzledine M.J., Close W.H., 2003. Nutrient Requirement Standards for Pigs. British Society of Animal Science. Brit. Soc. Anim. Sci., Penicuik 